\title{
Serum Bilirubin Binding Capacity and Free Bilirubin Concentration: A Comparison between Sephadex G-25 Filtration and Peroxidase Oxidation Techniques
}

\author{
WILLIAM J. CASHORE, ${ }^{(17)}$ PIERRE J. P. MONIN, AND WILLIAM OH \\ Department of Pediatrics, Women and Infants Hospital of Rhode Island, Section on Reproductive and \\ Developmental Medicine, Program in Medicine, Brown University, Providence, Rhode Island, USA
}

\section{Summary}

In 35 neonatal sera, comparisons were made of bilirubin binding capacity determined by Sephadex gel filtration and by peroxidase oxidation techniques. The serum indirect bilirubin concentration was $11.1 \pm 4.6 \mathrm{mg} / 100 \mathrm{ml}(190 \pm 79 \mu \mathrm{M} / \mathrm{liter})$; the serum concentration of unbound bilirubin was $50 \pm 60 \mu \mathrm{g} /$ $100 \mathrm{ml}(0.85 \pm 1.03 \mu \mathrm{M} /$ liter $)$ by gel filtration and $0.77 \pm 0.66$ $\mu \mathrm{g} / 100 \mathrm{ml}(0.013 \pm 0.011 \mu \mathrm{M} /$ liter $)$ by peroxidase oxidation. Binding capacity averaged $22.9 \pm 5.6 \mathrm{mg} / 100 \mathrm{ml}(392 \pm 96$ $\mu \mathrm{M} / \mathrm{liter})$ by gel filtration and $22.1 \pm 6.1 \mathrm{mg} / 100 \mathrm{ml}(378 \pm$ $104 \mu \mathrm{M}$ /liter) by peroxidase oxidation. The binding capacity, expressed as moles of bilirubin bound per mole of albumin, was $0.80 \mathrm{~mol}$ bilirubin/mol albumin by the Sephadex method and 0.77 by the peroxidase method. Individual values for binding capacity were in close agreement $(r=0.961, P<0.001)$. At saturation of the first bilirubin binding site, the unbound bilirubin concentration was $190 \pm 80 \mu \mathrm{g} / 100 \mathrm{ml}(3.25 \pm 1.37 \mu \mathrm{M} /$ liter) by gel filtration and $1.87 \pm 0.54 \mu \mathrm{g} / 100 \mathrm{ml}(0.032 \pm$ $0.009 \mu \mathrm{M} / \mathrm{liter}$ ) by peroxidase oxidation. There was no correlation between unbound bilirubin concentrations estimated by the two methods. The peroxidase method requires a smaller volume of serum than the Sephadex method and is more sensitive to small changes in free bilirubin concentration.

\section{Speculation}

Both Sephadex gel filtration and peroxidase oxidation techniques appear capable of predicting the indirect bilirubin concentration at which the first or "tight" bilirubin binding site will be saturated, and above which free bilirubin concentration will be greatly increased. In neonatal sera, the two methods showed close agreement for individual determinations of binding capacity over a wide range of molar ratios. The lower limit for the neurotoxic concentration of unbound or "free" bilirubin is not precisely known and may vary in the face of multiple clinical factors. However, it seems likely that free bilirubin concentrations in excess of those measured at saturation of the first binding site would be potentially neurotoxic, and that bilirubin bound to secondary binding sites would be more readily dissociable.

Estimation of serum bilirubin binding capacity in neonatal jaundice is possible by several methods $(2,4,8,11-13)$. Of these, the technique of gel filtration and column elution with Sephadex G-25 (2-4, 13) has several advantages over dye binding $(4,12)$ or displacement $(11)$ techniques: bilirubin itself is used to determine binding capacity and the method yields an estimate of binding capacity which can be expressed directly as indirect bilirubin concentration or as a molar ratio of bilirubin bound to albumin, rather than as a relative or reserve measurement of albumin saturation $(11,12)$. Disadvantages of the Sephadex technique include a large volume of serum required to perform the test (minimum of $0.1 \mathrm{ml} /$ column/determination or $0.6 \mathrm{ml} /$ assay) and an apparent inability of the technique to yield accurate estimates of free bilirubin concentration $(1,6-8)$. In the present study, an adaptation of the peroxidase method of Jacobsen and Wennberg (8) has been used to measure bilirubin binding capacity, and the results have been compared with results of quantitative Sephadex column elution on the same samples.

\section{MATERIALS AND METHODS}

Thirty-five sera were obtained from 26 jaundiced newborns between 3 and 7 days of age. The infants weighed between 680 and $4090 \mathrm{~g}$ and were between 25 and 41 weeks of gestation. Serum bilirubin and albumin concentrations were determined by standard methods $(5,9)$, and bilirubin binding capacity was measured by Sephadex G-25 gel filtration, according to a procedure previously described $(3,13)$. The concentration of "unbound" bilirubin recovered from the Sephadex columns was determined in chloroform at $450 \mathrm{~nm}$. Crystalline bilirubin (Sigma Chemical Co., St. Louis, MO) in chloroform solution had a molar absorbance of 59,600 at $450 \mathrm{~nm}$, so that an "unbound" bilirubin concentration of $0.058 \mathrm{mg} / 100 \mathrm{ml}(1.0$ $\mu \mathrm{mol} / \mathrm{liter}$ ) recovered from $100 \mu \mathrm{l}$ serum would have an optical density of 0.006 when extracted into $1.0 \mathrm{ml}$ chloroform. Bilirubin binding capacity was estimated by plotting the optical density of recovered bilirubin against total bilirubin concentration for each serum aliquot, as shown in Figure 1 (upper part). The $\mathbf{x}$ intercept of a line drawn through the optical density readings obtained was designated as the saturation point $(3,13)$, or total bilirubin binding capacity, of the serum. Using aliquots of the same serum, bilirubin binding capacity was also determined by use of the peroxidase oxidation technique described by Jacobsen and Wennberg (8). Aliquots of $25 \mu \mathrm{l}$ serum were added to 1.0

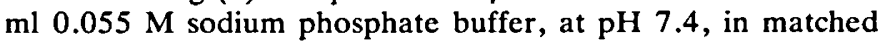
semimicrocuvettes of $1.0 \mathrm{~cm}$ path length. Freshly made crystalline bilirubin solution $(0.5 \mathrm{mg}$ bilirubin in $1.0 \mathrm{ml} 0.1 \mathrm{~N} \mathrm{NaOH})$. was added to the cuvettes; each $1.0 \mu$ l added bilirubin solution increased the bilirubin concentration of the sample by $2.0 \mathrm{mg} /$ $100 \mathrm{ml}$. Peroxidase oxidation of each patient serum was carried out for 7-10 increments of serum bilirubin concentration by measuring the 1-min change in optical density at $460 \mathrm{~nm}$ following the addition of peroxidase. The reactions took place at $24^{\circ}$ in a Gilford model 240 spectrophotometer (Gilford Instrument $\mathrm{Co}$., Oberlin, $\mathrm{OH}$ ) and the optical density changes were recorded continuously on a chart recorder. By this procedure, a titration curve could be obtained, as shown in Figure 1 (lower part). 
Free bilirubin concentration was calculated as

$\mathrm{UB}(\mu \mathrm{g} / 100 \mathrm{ml})$

$$
=\frac{\mathrm{V}_{0}(\Delta \mathrm{OD} / \mathrm{min})}{\mathrm{K}_{\mathrm{p}}(\Delta \mathrm{OD} / \mu \mathrm{mol} / \mathrm{liter} / \mathrm{min})} \times 585(\mu \mathrm{g} / \mu \mathrm{mol}) \times 0.1,
$$

where $\mathrm{UB}=$ the unbound or free bilirubin concentration of the sample, $\mathrm{V}_{0}=$ the 1-min absorbance change during the oxidation reaction, $K_{p}=$ the velocity constant or rate constant for horseradish peroxidase at a final concentration of $10 \mu \mathrm{g} / \mathrm{ml}$, and $585=$ the molecular weight of bilirubin. The same lot of crystalline peroxidase enzyme (Sigma) (activity 89 purpurogallin $\mathrm{U} / \mathrm{mg}$ ) was used for all determinations; fresh solutions of $1.0 \mathrm{mg}$ enzyme in $1.0 \mathrm{ml}$ deionized distilled water were prepared and standardized weekly or twice weekly, as needed, and were stable for 5 days at $4^{\circ}$. An enzyme concentration of $10 \mu \mathrm{g} / \mathrm{ml}$ was used in the clinical determinations (i.e., $10 \mu \mathrm{l}$ enzyme solution were added to $1.0 \mathrm{ml}$ buffer plus reagents). The rate constant, $\mathrm{K}_{\mathrm{p}}$, for the enzyme was determined by the method of Jacobsen and Wennberg (8), using freshly prepared aqueous bilirubin solutions with no albumin. Absorbance of these solutions, recorded for $2 \mathrm{~min}$, was stable until the addition of enzyme. An average of 11 weekly determinations gave a rate constant, $K_{p}$, of 3.35 $\pm 0.33 \Delta \mathrm{A} / \mu \mathrm{mol} / \mathrm{liter} / \mathrm{min}$ for oxidation of unbound bilirubin at an enzyme concentration of $10 \mu \mathrm{g} / \mathrm{ml}$. The correction factor for simultaneous dissociation and oxidation of bound bilirubin (8) was $-0.0018 \pm 0.0002 \Delta \mathrm{A} / \mu \mathrm{mol} / \mathrm{liter} / \mathrm{min}$ for infant sera (eight determinations).

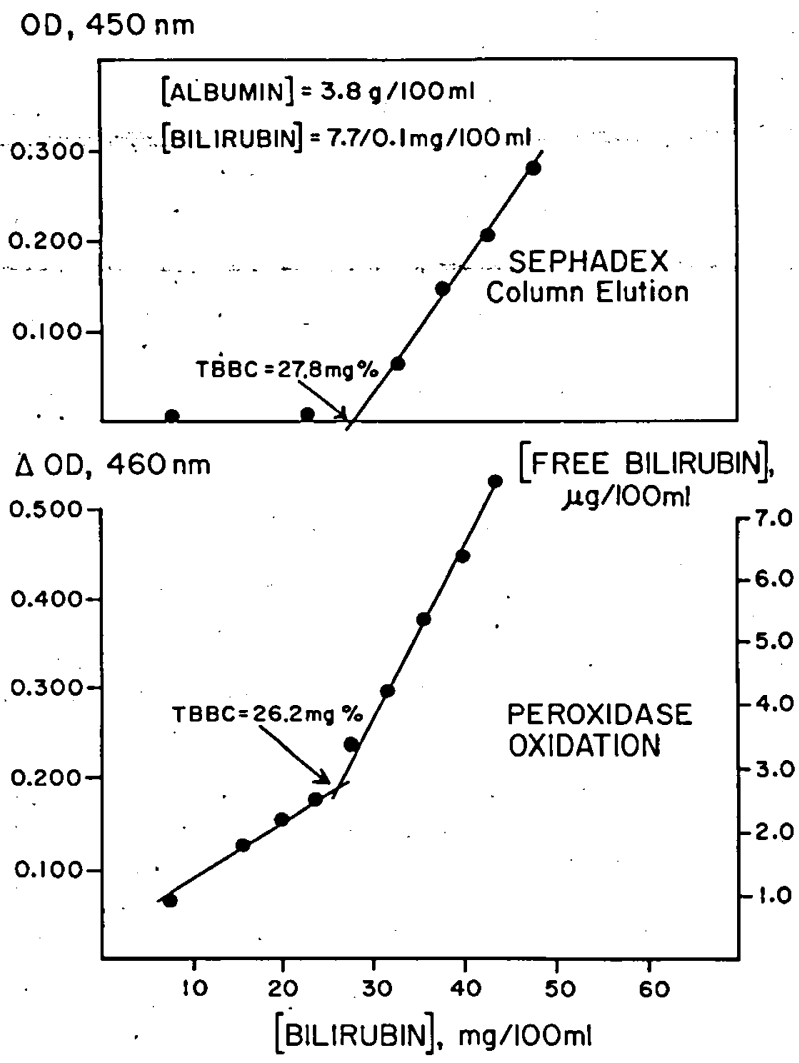

Fig. 1. Upper: bilirubin binding capacity by Sephadex gel filtration in serum of a newborn infant. $x$ axis: indirect bilirubin concentration. $y$ axis: optical density in chloroform, at $450 \mathrm{~nm}$, of bilirubin recovered from the Sephadex columns. Total bilirubin binding capacity $(\mathrm{TBBC})=$ $27.8 \mathrm{mg} / 100 \mathrm{ml}$. No free bilirubin is detectable at 7.6 or at $23.6 \mathrm{mg} / 100$ ml. Lower: same serum. Titration curve by the peroxidase oxidation method for estimation of bilirubin binding capacity and free bilirubin. $y$ axis: 1 -min optical density changes at $460 \mathrm{~nm}$ (left), and free bilirubin concentrations (right). TBBC $=26.2 \mathrm{mg} / 100 \mathrm{ml}$. First binding site appears to be saturated at a bilirubin:albumin molar ratio of 0.86 by Sephadex and 0.82 by the peroxidase method.
Reproducibility of the peroxidase titration method was assessed by duplicate determinations in 11 patient sera; the average difference between determinations of bilirubin binding capacity was $5.1 \pm 3.5 \%$, and between determinations of free bilirubin, $4.5 \pm 2.6 \%$ (mean $\pm \mathrm{SD}$ ).

\section{RESULTS}

Figure 1 (lower part) shows a typical titration curve on one infant's serum for the peroxidase oxidation technique. Between 7.6 and $23.6 \mathrm{mg} / 100 \mathrm{ml}$, there is a gradual increase in the rate of oxidation and in free bilirubin concentration. Between 27.6 and $43.6 \mathrm{mg} / 100 \mathrm{ml}$ there is an increase in the slope of the curve, indicating an increased rate of oxidation and a more rapid increase in free bilirubin concentration. Straight lines extrapolated from the two slopes intersect at $26.2 \mathrm{mg} / 100 \mathrm{ml}(448 \mu \mathrm{M} /$ liter); this concentration is the approximate limit of "tight" binding of bilirubin to albumin (i.e., binding of bilirubin to the first albumin binding site) and is considered as the bilirubin binding capacity for this sample. Bilirubin binding capacity of the same sample was $27.8 \mathrm{mg} / 100 \mathrm{ml}(475 \mu \mathrm{M} / \mathrm{liter})$ by Sephadex gel filtration (Fig. 1, upper part). Since the serum albumin concentration is $3.8 \mathrm{~g} / 100 \mathrm{ml}(550 \mu \mathrm{M} / \mathrm{liter})$, the binding capacity is $0.82 \mathrm{~mol}$ bilirubin bound/mol albumin by the peroxidase method and $0.86 \mathrm{~mol}$ bilirubin/albumin by the Sephadex method. Thirty-five comparisons of bilirubin binding capacity measured by Sephadex gel filtration and peroxidase oxidation techniques showed a high degree of correlation $(r=$ $0.961, P<0.001$ ) (Fig. 2).

Serum indirect bilirubin concentration was $11.1 \pm 4.6 \mathrm{mg} /$ $100 \mathrm{ml},(190 \pm 79 \mu \mathrm{M} / \mathrm{liter})$, and serum albumin concentration $3.4 \pm 0.5 \mathrm{~g} / 100 \mathrm{ml}$. $(492 \pm 72 \mu \mathrm{M} /$ liter $)$ for the $35 \mathrm{sera}$. At the initial serum bilirubin concentrations, free bilirubin concentration was $0.77 \pm 0.66 \mu \mathrm{g} / 100 \mathrm{ml}(0.013 \pm .011 \mu \mathrm{M} / \mathrm{liter})$ by the peroxidase method, and the estimated "unbound" bilirubin concentration was $50 \pm 60 \mu \mathrm{g} / 100 \mathrm{ml}(0.85 \pm 1.03 \mu \mathrm{M} / \mathrm{liter})$ by Sephadex column elution. Saturation of the first bilirubin binding site occurred at $22.1 \pm 6.1 \mathrm{mg} / 100 \mathrm{ml}(378 \pm 104 \mu \mathrm{M} /$ liter, bilirubin to albumin molar ratio $0.77 \pm 0.14$ ) by the peroxidase technique, and at $22.9 \pm 5.6 \mathrm{mg} / 100 \mathrm{ml}(392 \pm 96$ $\mu \mathrm{M} /$ liter, bilirubin to albumin molar ratio $0.80 \pm 0.13$ ) by the Sephadex column technique. Scatchard plots $(6,8)$ of the data obtained by peroxidase oxidation showed an average binding



Fig. 2. Comparison of results obtained for total bilirubin binding capacity by Sephadex and peroxidase methods in 35 infant sera: $\mathrm{r}=$ $0.961, P<0.001$. TBBC: total bilirubin binding capacity. 
Table 1. Comparison of bilirubin binding capacity and free bilirubin concentrations by Sephadex and peroxidase techniques in 35 neonatal sera

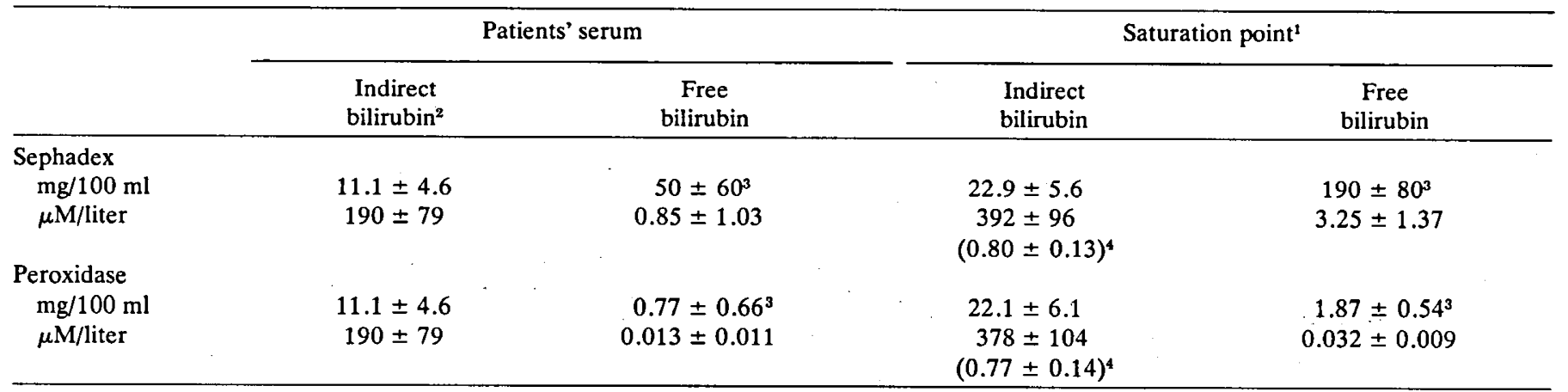

${ }^{1}$ Saturation point $(3,13)=$ the indirect bilirubin concentration at apparent saturation of the first bilirubin binding site.

2 Mean \pm 1 SD.

${ }^{3}$ Measured in micrograms per $100 \mathrm{ml}$.

4 Molar ratio of bilirubin to albumin.

capacity of $0.76 \pm 0.13 \mathrm{~mol}$ bilirubin bound/mol albumin, with the 35 individual determinations in good agreement; the association constant $\left(\mathrm{K}_{\mathrm{a}}\right)$ of bilirubin for albumin was $1.1 \pm 0.4 \times 10^{8}$ $\mathrm{M}^{-1}$. At the saturation point, free bilirubin was $1.87 \pm 0.54 \mu \mathrm{g} /$ $100 \mathrm{ml}(0.032 \pm 0.009 \mu \mathrm{M} /$ liter $)$ by the peroxidase method, and "unbound" bilirubin was $190 \pm 80 \mu \mathrm{g} / 100 \mathrm{ml}(3.25 \pm 1.37$ $\mu \mathrm{M} /$ liter) by the Sephadex method (Table 1 ). There was no correlation between free bilirubin levels determined by oxidation and those estimated by Sephadex column elution $(r=$ $0.319, P=\mathrm{NS}$ ).

\section{DISCUSSION}

The close agreement obtained between Sephadex and peroxidase techniques for estimation of bilirubin binding capacity indicates that both methods are able to predict an indirect bilirubin concentration above which the free bilirubin concentration will rise rapidly. The use of Sephadex gel filtration for clinical determination of bilirubin binding capacity is therefore given some independent support by the use of a sensitive method which does not depend on competition in vitro between albumin and another binding substance (Sephadex). However, "free" bilirubin concentrations estimated by the Sephadex technique exceeded the values obtained with peroxidase by approximately 100 -fold. The concentrations of "unbound" or "free" bilirubin obtained by gel filtration in the present study are similar to values for free bilirubin reported by Zamet and Chunga (15), who also used Sephadex columns. However, no correlation was found between the free bilirubin concentrations obtained by the Sephadex and by the peroxidase techniques. In the material studied and with the methods employed, Sephadex gel filtration appears to yield reasonable estimates of bilirubin binding capacity $(3,13)$, but appears incapable of yielding reliable estimates of free bilirubin concentration. Compared to values obtained with the more sensitive peroxidase assay, the recovery of much higher concentrations of bilirubin from Sephadex columns indicates that some loosely bound as well as unbound bilirubin may be adsorbed in the column bed.

The adsorption of loosely bound as well as free bilirubin by the Sephadex column would tend to promote further dissociation of bilirubin from weaker binding sites, to maintain equilibrium between free and bound bilirubin, as the serum passes through the column. The bilirubin measured as the unbound fraction would then represent the total amount of bilirubin adsorbed, rather than the free bilirubin initially present in the serum. In the enzymatic determination, free bilirubin concentration is estimated from the initial oxidation rate, which has been shown to be proportional to the free bilirubin concentration at the start of the reaction $(7,8)$.

Our findings with the peroxidase method for bilirubin binding capacity and free bilirubin concentrations in neonatal sera are similar to the results of Jacobsen and Wennberg (8), Nelson et al. (10), and Wennberg et al. (14). Jacobsen and Wennberg showed in vitro that purified adult albumin (Cohn fraction V) had the same binding capacity ( $1 \mathrm{~mol}$ bilirubin/mol albumin) by Sephadex and peroxidase techniques of measurement (8); the present findings confirm that there is also a consistent close agreement between the two techniques for infant sera over a wide range of gestational ages and at molar ratios varying between 0.51 and $1.04 \mathrm{~mol}$ bilirubin bound/mol albumin.

In these studies, the difference between normal body temperature $\left(37^{\circ}\right)$ and the lower temperature $\left(24^{\circ}\right)$ employed for control of the reaction rate was compensated for by standardizing all components of the peroxidase reaction at the lower temperature; this correction does not preclude the possibility that equilibrium concentrations of free bilirubin in vivo and at higher temperatures might differ somewhat from those reported here. The dilution $(1: 40)$ employed to permit the use of small samples might also tend to produce an underestimate of in vivo free bilirubin concentrations by reducing the effects of weak competitors for bilirubin binding sites. Although technically more difficult, free bilirubin determinations would most nearly approximate in vivo conditions if they were performed in undiluted serum at physiologic temperature.

There was good agreement for measurements of bilirubin binding capacity between the peroxidase titration curves as described and Scatchard plots of the same data. As illustrated in Figure 1, serial increases in free bilirubin with addition of bilirubin to the sample, as well as the similarities and differences in results between the peroxidase and Sephadex techniques, were more conveniently represented by the use of titration curves in this study.

Compared to the Sephadex column method, the working time for peroxidase titration is similar (40-45 min); single specimens can be analyzed for free bilirubin in 5-10 min. The amount of serum required for peroxidase titration (200-250 $\mu \mathrm{l}$ for 8-10 determinations) is substantially less than for Sephadex gel filtration (100 $\mu \mathrm{l} /$ column). Although the technique of peroxidase oxidation is more complicated and requires more sophisticated equipment, the procedure is capable of yielding more information than the Sephadex method. In addition to the binding capacity of the first albumin binding site and the free bilirubin concentration, the association constant (binding affinity) of the first binding site can also be determined $(6,8)$. Appropriate clinical interpretation of free bilirubin determinations will require further study. At present, prediction of clinical outcome based on free bilirubin measurements has not been established. The clinical utility of both methods for measurement of bilirubin binding and the applicability of our present findings to the management of individual patients should be further verified by prospective observations of long term as well as short term clinical outcome. 


\section{CONCLUSION}

Serum bilirubin binding capacity and unbound bilirubin concentrations were measured simultaneously by Sephadex gel filtration and horseradish peroxidase oxidation in 35 neonatal sera. Comparison of results showed good agreement between the two techniques for determination of bilirubin binding capacity, but no correlation between the two methods for unbound (free) bilirubin concentration. The column method yielded unbound bilirubin concentrations approximately 100 times greater than the peroxidase method, probably as a result of adsorption of loosely bound as well as unbound bilirubin in the column bed. Both methods give similar estimates of the serum indirect bilirubin concentration at which the first albumin binding site for bilirubin will be saturated; the peroxidase method is the more sensitive one to low levels and small changes of serum free bilirubin concentration.

\section{REFERENCES AND NOTES}

1. Beaven, G.H., d'Albis, A., and Gratzer, W. B.: The interaction of bilirubin with human serum albumin. Eur. J. Biochem., 33: 500 (1973).

2. Blondheim, S. H., Kapitulnik, J., Valaes, T., and Kaufmann, N. A.: Use of a Sephadex column to evaluate the bilirubin-binding capacity of the serum of infants with neonatal jaundice. Israel J. Med. Sci., 8: 22 (1972).

3. Cashore, W. J., Karotkin, E. H., Stern, L., and Oh, W.: The lack of effect of phototherapy on serum bilirubin binding capacity in newborn infants. J. Pediat., 87: 977 (1975).

4. Chan, G., Schiff, D., and Stern, L.: Competitive binding of free fatty acids and bilirubin to albumin: Difference in HBABA dye versus Sephadex G-25 interpretation of results. Clin. Biochem. 4: 208 (1971).
5. Doumas, B. T., Watson, W. A., and Biggs, H. G.: Albumin standards and the measurement of serum albumin with bromcresol green. Clin. Chim. Acta, 31: 87 (1971).

6. Jacobsen, J.: Binding of bilirubin to human serum albumin-determination of the dissociation constants. FEBS Lett., 5: 112 (1969).

7. Jacobsen, J., and Fedders, O.: Determination of non-albumin-bound bilirubin in human serum. Scand. J. Clin. Lab. Invest., 26: 237 (1970).

8. Jacobsen, J., and Wennberg, R. P.: Determination of unbound bilirubin in the serum of newborns. Clin. Chem., 20: 783 (1974).

9. Martinek, R. G.: Improved micromethod for determination of serum bilirubin. Clin. Chim. Acta, 13: 161 (1966).

10. Nelson, T., Jacobsen, J., and Wennberg, R. P.: Effect of $\mathrm{pH}$ on the interaction of bilirubin with albumin and tissue culture cells. Pediat. Res., 8: 963 (1974).

11. Odell, G. B., Cohen, S. N., and Kelly, P. C.: Studies in kernicterus. II, The determination of the saturation of serum albumin with bilirubin. J. Pediat., 74: 214 (1969).

12. Porter, E. G., and Waters, W. J.: A rapid micromethod for measuring the reserve albumin binding capacity in serum from newborn infants with hyperbilirubinemia. J. Lab. Clin. Med., 67: 660 (1966).

13. Schiff, D., Chan, G., and Stern, L.: Sephadex G-25 quantitative estimation of free bilirubin potential in newborn infants' sera: A guide to the prevention of kernicterus. J. Lab. Clin. Med., 80: 455 (1972).

14. Wennberg, R. P., Lau, M., and Rasmussen, L. F.: Clinical significance of unbound bilirubin [Abstr.]. Pediatr. Res., 10: 434 (1976).

15. Zamet, P., and Chunga, F.: Separation by gel filtration and microdetermination of unbound bilirubin II. Study of sera in icteric newborn infants. Acta Paediat. Scand., 60: 33 (1971).

16. The present address of Dr. P. J. P. Monin is: Maternité Régionale A. Pinard, Rue du Docteur Heydenreich, Centre de Prématurés, 54042 Nancy-Cedex, France.

17. Requests for reprints should be addressed to: W. J. Cashore, M.D., Department of Pediatrics, Women and Infants Hospital of Rhode Island, 50 Maude St., Providence, RI 02908 (USA).

18. Received for publication January 31,1977 .

19. Accepted for publication June 10, 1977. 